\title{
Politik Kuramlarda Tabiat Durumunun Anlamı Üzerinden Mad Max Fury Road Filminin Eleştirisi
}

\author{
Ali Gürbüz*
}

\section{Özet}

Tabiat durumu, toplum kavramının gelişmesinden önceki dönemi ifade eden bir kavramsallaştırmadır. Filozoflar tabiat durumunu toplum haline geçişi ve siyasal yapıların kuruluşunu gerekçelendirmek için ele alırlar. Siyaset felsefesi yapan filozoflardan Platon'un, Rousseau'nun, Hobbes'un ve Nietzsche'nin tabiat durumuyla ilgili tasvirlerini distopik kurmacalarda da görmek mümkündür. Adı geçen filozoflar doğa durumunu bir çeşit savaş olarak yorumlarlar. Çünkü doğa durumunda içtepi ve isteklerin egemenliği altındaki insanlarm birbirleriyle ilişkilerini düzenleyen normlar ortadan kalkmış, doğal kaynaklardan faydalanmak muharebe düzenini zorunlu hale getirmiştir. Toplum yaşamına geçiş bu muharebe düzenini ortadan kaldıran ahlaki ve siyasal normlarm gelişmesinden doğar.

Distopik eserlerdeki hem doğa hem de toplumsal yaşamla ilgili öngörüleri doğa durumuna geri dönüş olarak yorumlamak mümkündür. Mad Max: Fury Road (George Miller, 2015) filminde de insanlarm bir arada yaşamasını mümkün hale getiren tüm normların ortadan kalktığı ve yaşamsal kaynakların güç sahiplerinin kontrolünde olduğu bir yaşam biçimi anlatılır. Bu yaşam biçimine ait tasvirler doğa durumu tasvirleriyle benzerlik gösterir. Bu çalışmanın amacı Mad Max: Fury Road filmi örneği üzerinden doğa durumu ve distopik tasavvurlar arasindaki ilişkiyi politik kuramlardaki doğa durumu yaklaşımlarnyla çz̈zümlemektir. Çözümlemede ilgili filozoflarn doğa durumu tasavourlarna değinilecek ve filmdeki sinemasal imgeler bu tasavourlarla yorumlanacaktır.

Anahtar kelimeler: Mad Max: Fury Road, Doğa Durumu, Distopya

*ORCID: 0000-0001-6509-7411

E-Mail: aligurbuz1967@hotmail.com

DOI: $10.31122 /$ sinefilozofi.682973

Geliş Tarihi - Recieved: 15.01.2020

Kabul Tarihi - Accepted: 01.05.2020 


\title{
Criticism of Mad Max Fury Road through the Meaning of the State of Nature in Political Theories
}

\begin{abstract}
Ali Gürbüz*
Abstract

The state of nature is a conceptualization that refers to the period before the development of the concept of society. Philosophers handle nature status to justify the transition to society and the establishment of political structures. It is also possible to see the depictions of Plato, Rousseau, Hobbes and Nietzsche, who are philosophers of political philosophy, in the dystopic fiction. These philosophers interpret the state of nature as a kind of war. Because, in the state of nature, norms that regulate the relations of people under the domination their desires have disappeared, and benefiting from natural resources has made the battle compulsory. The transition to social life arises from the development of moral and political norms that eliminate this combat order.

It is possible to interpret both nature and social predictions in dystopic works as a return to the state of nature. Mad Max Fury Road (George Miller, 2015) describes a way of life in which all norms that make it possible for people to live together disappear and where vital resources are under the control of power holders. Descriptions of this lifestyle are similar to those of the state of nature. The aim of this study is to analyze the relationship between the state of nature and dystopic conceptions with the approach of the state of nature in political theories through the example of Mad Max Fury Road. In the analysis, the natural state conceptions of the related philosophers will be mentioned and the cinematic images in the film will be interpreted with these conceptions.
\end{abstract}

Key Words: Mad Max: Fury Road, State of Nature, Dystopia

\footnotetext{
*ORCID: 0000-0001-6509-7411

E-Mail: aligurbuz1967@hotmail.com

DOI: 10.31122/sinefilozofi.682973

Received - Geliş Tarihi: 15.01.2020

Accepted - Kabul Tarih : 01.05.2020
} 


\section{Giriş}

Ütopyalarda her şeyin iyi olacağına dair umudu, distopyalarda ise her şeyin kötü olacağına dair umutsuzluğu okuruz. Ütopyalarda tabiat durumundan çıkarak daha üstün bir toplumsallığa ulaşıldığını, post-apokaliptik distopyalarda ise bazı politik kuramlarda olumsuz olarak açıklanan tabiat durumuna geri dönüldüğünü görürüz. Ancak her ikisinde de 'tabiat durumunun tasvirleri'ne ulaşırız. Emil Cioran, "birbirine hiç benzemez görünen iki tür, ütopyacı ve kıyametçi türler birbirinin içine geçer, birbirine renk verir" (Cioran, 1999:97) diye yazmaktadır. Politik kuramlar ve post-apokaliptik distopik eserler, tabiat durumuna dair felsefi çıkarımlarda bulunmamıza imkân verir. Tabiat durumuyla ilgili negatif kuramsal yorumlar, demokratik toplumsallıklarımızın varlığının gerekçelerini bize sunar. Demokratik toplumsallıkların öncesi olarak tabiat durumunun filozofların düşüncelerindeki kavranışı, uygarlığımızın gelişim merhalelerini okumak açısından tarihsel bir perspektif oluşturur. Tabiat durumunu felsefi imgeler ile oluşturmuş filozofların düşüncelerinden yola çıkarak yapılacak bir okuma, demokratik devletin mantıksal misyonunu tamamlaması halinde, insanlığın negatif olarak yorumlanan bu tabiat durumuna geri dönüşüne dair çıarım yapmaya imkan verebilir. George Miller'ın Mad Max: Fury Road (2015) filmi, Nietzsche' nin öngörüsü olan, demokratik devletin mantıksal misyonunu tamamlaması sonrasında insanlığın içine sürükleneceği tabiat durumunu sinematografik imgeler haline getirmiş olması sebebiyle, tabiat durumuna dair yapılacak felsefi bir eleştiriye kaynaklık edebilir. Bu makale, tabiat durumuna dair felsefi izahatlarda bulunmuş filozoflar üzerinden, Mad Max: Fury Road filminden de yararlanarak, demokratik toplumsallıkların mantıksal misyonunu tamamlaması halinde insanlığı bekleyen tekinsizliğe değinmeye çalışacaktır.

\section{Tabiat Durumundan Çıkış: Felsefi İzahatlar}

Ütopyalarda tabiat durumunun tehlikelerinden uzaklaşarak kurulan daha iyi bir toplumsallığın tasvirini, post-apokaliptik distopyalarda ise demokratik devletin mantıksal misyonunu tamamlamasından sonra her türden tehlikenin baş gösterdiği tabiat durumunun tasvirini buluruz. Cambridge Edebiyat Araştırmaları Bölümü'nde Gregory Claeys tarafından derlenmiş olan Ütopya Edebiyatı adlı çalışmada, Claeys'in Distopya'nın Kökenleri: Wells, Huxley ve Orwell adlı makalesinde, "distopya, sık sık anti-ütopya ya da olumsuz ütopya ile değişmeli olarak kullanılabilmektedir; [distopyalar] kesinlikle kaçınmamız gereken yaşam biçimlerini göstermek ister" (Claeys, 2017:156) diye yazmıştır. Distopyaların tarihini ayrıntılı olarak inceleyen bu eserde, distopyalardan, modern bilimsel, toplumsal, iktisadi gelişmelerin insanlı̆̆1 ulaştıracağı geleceklerin betimlendiği eserler olarak söz edilmektedir.

Tabiat durumunun filozoflar tarafından yapılan tasviri, felsefe tarihinde birbirinden farklı filozoflarda farklı veçheler üzerinden anlatılmıştır. Makalede, tabiat durumuna dair filozofların düşünceleri kronolojik bir sıraya göre aktarılmamaktadır. Bu yöntemin tercih edilmesinin sebebi, metnin düzeninde ortaya çıan bağlamlara göre bu filozofların düşüncelerine yer verilecek olmasıdır.

Klasik ve modern filozofların üzerinde uzlaştıkları nokta, tabiat durumuna üstün bir yaşantının politik kuram ile geliştiğidir. Tabiat halini aşmak yoluyla kurulan politik düzen, tabiat halinde var olan tehlikeleri ortadan kaldırarak daha üstün bir yaşantıya kaynaklık 
etmiştir. Tabiat hali tasvirlerinde can güvenliğinin olmayışı, yaşamm tekinsiz ve meşakkatli oluşu belirgin niteliklerdendir. Tabiat halinden toplum haline geçiş teorik olarak izahat edilmeksizin, insanlığın gelişiminin merhaleleri açığa çıkarılamayacağından, filozofların tabiat hali hakkındaki felsefi izahatları üzerinde önemle durulması gereken bir konudur. Herkesin mutluluktan payını alacağı vaadini barındıran politik kuramlar, tabiat halinde var olan mutsuzluğu göstererek politik kuramlarına haklılık kazandırmışlardır.

Distopik bir film olarak Mad Max: Fury Road, demokratik toplumsallı̆̆ın çöküşü sonrası ortaya çıkması muhtemel tabiat hali tasvirleri ile distopik geleceğin tehlikeleri hususunda insanlığı uyarır. Ütopik ve distopik metinlerin tabiat hali tasvirleri, demokratik toplumsallığın önemini ve hayatiyetini anlatmaya imkân sunmaktadır.

Ütopik düşünce, tabiat halinin tasviri aracılığıyla, tabiat halinin kötülüklerini aşan bir toplumsallıkta 'her şeyin iyi olacağı' düşüncesini akılcılaştırmıştır. Platon, Devlet adlı kitabında, herkesin mutluluktan payını alacağı bir devleti kurmaya çalıştığını vurgular (Platon, 2003:100). Toplumun kuruluşunu, tek başına yaşarken kendi kendine yetemeyen insanların birbirine duydukları gereksinimlere dayandırmıştır. Platon, "toplumu yapan, insanın tek başına, kendi kendine yetmemesi, başkalarını gereksemesidir" (Platon, 2003:56) diye yazar. Antik felsefede, tabiat halinde, tek başına olduğunda, kendi kendine yetebilecek tabiata sadece filozof olan sahiptir. Devletli toplumsallıklar, kendi kendine yetemediği için başkalarına ihtiyaç duyanlar tarafından, tabiatlarının eksik yanına çare olsun diye bir gereksinimden dolayı oluşturulmuştur. Filozof, toplum halinde yaşamayı, filozof olmayanlar için, herkesin mutluluktan payına düşeni alacağı vaadiyle tasarlamıştır. Filozof bir toplumsallığa bağlanmaya ihtiyacı olmayandır. Filozof, filozofun yokluğunda insanların içine sürüklendiği çıkmazlara, kötülüklere çare bulmak için devleti tasarlamıştır. Devlet kitabı, filozofun kuram ile eylem yakınlığını esas alarak oluşturduğu bir siyaset kitabıdır. Platon, teorik etkinlik ile pratik etkinliğin yakınlığını Devlet kitabında, "bir şeyi anlattığımız gibi uygulamak mümkün müdür?" diye sorduktan sonra, "tasarımımıza en yakın devleti kurmanın yolunu bulabilirsen artık kabul et ki istediğini yapmış, devletimizin mümkün olduğunu, yeterince göstermiş olurum" (Platon, 2003:148) diyerek açıklar. Anlatıldığ1 gibi uygulanabilen bir tasarım, kuram ile eylem yakınlığının üzerine inşa edilmiştir. Uygulanabilir bir kuram yazarak Platon, tabiat halinde mutlu olmayanlara, tabiat halinde can güvenliği dahi olmayanlara ortak mutluluğu esas alan bir toplumsallığın hangi ilkelere dayanarak kurulacağını öğretir. Tabiat halinden çıkarak toplum haline geçen insanlar, tabiat halinde tehlikelerle çevrili yaşamlarını sürdürmekten yorulmuşlardır. Filozofun aklı, tabiat halinde kaçma ve kovalamaca içerisinde düşünmeye fırsatı dahi olmayanlara, sükûnet içerisinde yaşayacakları yeni bir düzen tesis eder.

J.J. Rousseau, "her türlü tasarıda göz önünde tutulması gereken iki şey vardır: ilk olarak, tasarının mutlak iyiliği; ikinci olarak da uygulamanın kolaylığı" dır (Rousseau, 2015:4) der. Eylemlere uygulanabilir bir kuram yazmak, filozofun her şeyin iyi olacağına dair inancının bir sonucudur. Herkesin ortak mutluluğunu amaçlayan ve uygulanabilir bir siyasal tasarım, siyaset filozoflarının kurgulara yenik düşmesini engeller. Siyasal tasarımlar söz konusu ölçütler üzerinden, daha iyi bir toplumun kuruluşunun gerekçelerini sunarlar.

Spinoza, Tractatus Politicus adlı kitabında insanların ortak mutluluğa ortak yasalar olmaksızın varamayacağını belirtmiş ve "uygulaması olan tüm bilimler arasında, kuramın eylemden en çok farklılık gösterdiği bilim, siyasettir" (Spinoza, 2007:11) diye yazmıştır. Siyaset, 
uygulaması olan bir bilim olduğundan, siyasal bir kuram, mutlu bir toplumsallı̆̆ın bilimini yapan filozofun düşünceleriyle oluşturulmuştur. Kuram ile eylemin birbirine yakın olması, filozofun ütopik/hayalci olarak yargılanmasını engellemiştir.

İk siyasal tasarım olan Devlet kitabından bu yana filozoflar uygulanabilir kuramlar yazmaya çabalamışlardır. Filozoflar tasarımlarının tabiat haline kıyasla mutluluk taşıdığını ve daha üstün olduğunu kanıtlamak için tabiat halinin tehlikelerini dayanak olarak almışlardır. Felsefe tarihi filozofların tabiat halinden toplum haline geçişin farklı teorik açıklamalarını sunar. Nietzsche, toplum haline geçişin nedeni hakkında "insan aynı zamanda zorunluluk ve can sıkıntısı yüzünden toplum ve sürü halinde yaşamak istediğinden, bir barış kararına ihtiyaç duyar ve en azından en kaba 'bellem omnium contra omnes' in (herkesin herkese savaşı) yok olmasına bakar" (Nietzsche, 2005:107) açıklamasını yapmıştır. Toplum hali, tabiat halinde var olan bazı zorunluluklar sebebiyle herkesin isteği haline gelmiştir. Nietzsche'nin ifadesinin açıkça belirttiği gibi, tabiat halinde herkesin herkese savaşı vardır. Bu savaş hali, her insanı tehdit ettiğinden, barış içerisinde yaşamaya yönelik bir istekle tehditleri ortadan kaldıran bir toplumsallık icat edilmiştir. Toplumsallığın kuruluşu barış kararına dair söz vermeyi ve bu söz etrafında toplumsallığın üyelerinin birbirlerine itimat duymasını gerektirir. Tabiat halinde herkesin herkesten şüphe duyduğu koşullarda kişilerin birbirlerine itimat duymaması, tinsel olarak insanları güven içinde yaşayabilecekleri bir toplumsallık kurmaya yöneltmiştir.

Platon, toplumun, tabiat halinde sağlanması mümkün olmayan gereksinimlerden doğduğunu belirtmiştir. Tabiat halinde olmayan güvenlik, yeni kurulan toplumsallıkta sağlanan gereksinimlerdendir. İlk toplumsal sözleşme, doğadan kaynaklanmayan yanı sebebiyle, 'ütopik' bir nitelik taşır. Mutlu bir yaşantı arayışı tabiattan çıkışı gerektirmiştir. Toplumsal sözleşme, içinde taşıdığı 'mutluluk vaadi' sebebiyle ütopiktir. Platon, “biz devletimizi, bütün topluma birden mutluluk sağlasın diye kuruyoruz" (Platon, 2003:99) dediğinde bu, toplumsallığın kuruluşuna katılacak olanları ütopyaya davetidir aynı zamanda.

Rousseau, toplum sözleşmesinin tabiat haline üstünlüklerinden söz etmiş ve tabiat halinde olmayan can güvenliğinin sözleşmeyle garanti altına alındığını vurgulamıştır. Rousseau, toplumun nereden kaynaklandığını şöyle açıklar: "toplum düzeni (...) hiç de doğadan gelme değildir, sözleşmelere dayanmaktadır." (Rousseau, 2013:4). Tabiat halinde herhangi bir zamansal ve toplumsal düzenlemeye tabi olmayan, "tek başına, aylak, avare her zaman da tehlikeyle karşı karşıya olan vahşi insan" (Rousseau, 1995:101), bir sözleşme dolayımıla Rousseau'nun ifadesiyle 'hayvandan insana' geçiş yapmıştır. Rousseau bu durumu şöyle izah eder:

“Doğal yaşama halinden toplum düzenine geçiş, insanda çok önemli bir değişiklik yapar: Davranışındaki içgüdünün yerine adaleti koyar, daha önce yoksun olduğu değer ölçüsünü verir ona. Ancak, ödevin sesi içtepilerin, hak da isteklerin yerini alınca, o güne kadar yalnız kendini düşünen insan başka ilkelere göre davranmak, eğilimlerini dinlemezden önce aklına başvurmak zorunda kalır (...) O anı ki, kendini akılsız ve gelişmemiş bir hayvan durumundan çıarıp akıllı bir varlık, bir insan haline sokmuştur." (Rousseau, 2013:18)

Toplum sözleşmesi doğa durumundan çıkışı sağlamış, böylece insan için daha üstün bir yaşantı varlık bulmuştur. Doğa durumunda sadece kendini düşünerek içgüdülerine göre hareket eden, içtepi ve isteklerine uyan insan, toplum sözleşmesi ile yeni 'haklar' kazanmış aynı zamanda bazı 'ödevlere/yükümlülüklere' göre davranmayı taahhüt etmiştir. 
Hobbes Leviathan'da, tabiat halinde yaşamın kısa, kötü, yoksul ve vahşi olduğunu yazmıştır. Leviathan'ın herkesin herkese savaşının olduğu tabiat haline son verdiğini söylemiştir. "Devlet olmadıkça, herkes herkese karşı daima savaş halindedir" (Hobbes , 2013: 101) diye yazan Hobbes, metninin ilerleyen kısımlarında şunları yazmıştır:

"böyle bir ortamda, çalışmaya yer yoktur; çünkü çalışmanın karşılığı belirsizdir: dolayısıyla toprağın işlenmesine de yer yoktur; ne denizcilik; ne deniz yoluyla ithal edilebilecek malların kullanılması; ne rahat yapılar; ne daha fazla güç gerektiren şeyleri kaldırmak ve taşımak için gerekli şeyler; ne yeryüzü hakkında bilgi; ne zaman hesabı; ne sanat; ne yazı; ne de toplum vardır. Hepsinden kötüsü, hep şiddetli ölüm korkusu ve tehlikesi vardır; ve insan hayatı yalnız, yoksul, kötü, vahşi ve kısa sürer" (Hobbes, 2013: 101) .

Tabiat durumunda hep şiddetli ölüm korkusu altında yaşayan insanlar, toplum kavramından uzak bir biçimde vahşi yaşam koşullarında olduklarından, olası savaş koşullarına son verecek olan Leviathan, tabiat durumuna üstün bir yaşantıyı sağlar.

Filozoflar tasarımlarinda tabiat halinin tehlikelerini vurgulamak hususunda ortak görüşlerde birleşmişlerdir. Platon'un Devlet'i, Hobbes'un Leviathan'1, Rousseau'nun Toplum Sözleşmesi, Nietzsche'nin analizleri tabiat haline üstün bir toplumsallığın kuruluşuna haklılık kazandırmıştır. Filozoflar, mutlu bir toplumsallığın kuruluşunda tabiat halinden çıkışı amaçlamıştır.

Tabiat halinden devletli toplumlara geçiş yapılmasıyla demokrasi kavramı önem kazanmıştır. Spinoza demokrasiyi, tabiat halinde var olan özgürlüğün garanti altına alındığı, yurttaşların itaate zorlanmadığı ve her kişinin kendi aklının kılavuzluğunda olduğu bir toplumsallık olarak açıklamıştır. Devletli toplumsallıkların Spinoza'nın demokrasi kavrayışından uzaklaşmasının sonucunda, Nietzsche' nin distopik öngörüsü olan şu ifade tüm uyarıcılığıyla insanlığın önündedir :

“Yöneten her şeye karşı güvensizliğin, bu kısa soluklu savaşımların yararsız ve yıpratıcı yönünü kavrayışın, insanları tamamen yeni kararlar almaya: devlet kavramını ortadan kaldırmaya, "özel ve kamusal" karşıtlığını yok etmeye zorlaması gerekir...Devletin hor görülmesi, çöküşü ve ölümü, özel kişinin (birey demekten kendimi sakınıyorum) zincirlerinden kurtulması, demokratik devlet kavramının mantıksal sonucudur; bu kavramın misyonu budur" (Nietzsche, 2003: 310).

$\mathrm{Bu}$ çerçevede tabiat halinden çıkılmasını amaçlayan kuramları, her şeyin iyi olacağı inancının sarsıldığı distopyalar çağının girişinde, yeni bir perspektifle değerlendirmek mümkündür. Ütopyalarda tabiat halinden daha üstün ve herkesin mutluluktan payını alacağ1 bir yaşam iddiasını, distopyalarda ise yeniden tabiat haline dönüşün işaretlerini görebilmek mümkündür. Distopyalar, insanlığı, yaklaşan gelecek hakkında uyaran metinler olarak değerlendirildiğinde, distopyalardaki tabiat tasvirlerinin önemi daha belirginleşir.

Bu makale, bir distopya örneği olarak Mad Max: Fury Road filmi üzerinden tabiat halini filozofların düşünceleri aracılığıyla değerlendirmeye çalışacaktır. Film evrenini oluşturan öğeler, adı geçen filozofların tabiat hali tasvirleriyle benzerlik oluşturmaktadır. Açlığın ve susuzluğun neden olduğu şiddet ilişkilerinin hüküm sürdüğü ve bu şiddeti ortadan kaldıracak bir otoritenin var olmadığı koşullarda, mevcut uygarlığın geleceğinin, filozofların kuramlarında uzaklaşmayı amaçladığı tabiat haline benzer bir yaşama geri dönüleceği düşüncesini iletir. 


\section{Mad Max: Fury Road Filminin Felsefi Bağıntılarına Dair Analiz}

Mad Max: Fury Road filmi, yönetmen George Miller tarafından Mad Max filmlerinin devamı niteliğinde çekildi. Filmin, diğer Mad Max filmleriyle benzer cehennemi atmosferi ve aksiyon sahneleri, estetik açıdan yeni gelişen teknolojilerin de yardımıyla, görkemli bir anlatı oluşturulmasına katkı sağlamıştır. Bu filmin diğer filmlerden bağımsız olarak çözümlenmeye değer anlatı yapısı, onu, XXI. yüzyılın paranoyak medeniyet tasavvuru ile aynı döneme rastlamış olması sebebiyle ayrıca yorumlanmaya değer kılıyor.

İnsanlığın binlerce yılda düşünsel süreçlerden geçerek oluşturduğu medeniyet içine sürüklendiği kriz Mad Max: Fury Road filmi üzerinden değerlendirilebilir. Distopya filmleri, insanlığın akıbetine dair sakınılması gereken gelecek tasavvurlarını bize sunduğundan, postapokaliptik bir film olarak Mad Max: Fury Road, insanlığın ulaşmayı arzu duymayacă̆ı karanlık geleceğin emarelerini değerlendirmeye imkân veriyor. Distopya üzerine yapılan kültürel analizlerde, bu eserlerin geleceğe dair bir uyarı taşıdığı vurgulanmaktadır. Ütopya/Distopya Tarihsel Olasılı̆̆ın Koşulları adlı kitapta, distopyaların üzerinde inşa edildiği gelecek tasavvurunun tamamıla hayal ürünü olmadığı vurgulanır. Söz konusu gelecek tasavvurları, bir ihtimal de olsa gerçekleşme potansiyeli taşımaktadır. Distopyaların bu karanlık niteliğinin gerçekleşmemesi, yaşanmakta olan çağdaki semptomlarının farkına varılmasına ve düzeltilmesine bağlıdır. "Distopya bizi karanlık ve bunaltıcı gerçekliğin tam ortasına bırakır, burada ve şimdiki semptomlarının ayırdına varıp tedavi etmezsek gelecek olan korkutucu bir geleceği önümüze koyar" (Gordin, Tilley, \& Prakash, 2018:8). Mad Max: Fury Road filmi, bir distopya örneği olarak, karanlık ve bunaltıcı gerçekliğin sinematografik açıdan etkili eserlerinden biridir.

Film, uçsuz bucaksız çöllerde, susuzluğun hüküm sürdüğü, insanların bedbaht haller içerisinde olduğu, böceklerin yiyecek olarak tüketildiği, tarımın neredeyse imkânsız olduğu koşullarda, yaşama korkunun egemen olduğu bir toplumu sinematografik olarak aktararak başlar. Kısmi anlamda var olan petrole sahip olmak için bir avuç suda fırtınaların koptuğu bir dönem anlatılır. Şiddetin Arkeolojisi İlkel Toplumlarda Savaş adlı kitabında Pierre Clastres'nin, ilkel toplumlarda savaşın insanlar arası ilişkilerin özüne ait olduğunu vurguladığı saptamasındaki gibi, savaşın yaşamsal ilişkilere yön verdiği bir dönem başlamıştır. Clastres'nin tespiti şöyledir: "Savaş, ilkel toplumun özüne aittir; tıpkı mübadele gibi, ona ait bir yapıdır" (Clastres, 2017:38). Mad Max: Fury Road filmi, ilkel toplumun özüne ait olan savaşın yeniden baş gösterdiği tarih sonrası günleri anlatmaktadır. Yaşamın kaynağı olan su, neredeyse yok denilecek haldedir. Suya sahip olan ve bu hâkimiyeti yaşamin denetimine çevirmiş bir grubun, insanlığı barbar bir biçimde yönettiği koşullarda; yaşam, korku ve tedirginlik altında sürüp gitmektedir. Ölümsüz Joe (Hugh Keays-Byrne), adı verilen tiran, keyfine göre su kaynaklarını Hisar adlı dağdan aşağıya salmakta ve suyu saklayacak eşyaları dahi olmayan insanlar birbirleriyle savaşarak susuzluklarını kısmi anlamda yatıştırmaya çalışmaktadırlar. İnsanlık onuru ortadan kalkmış, bir tiranın iki dudağı arasına sıkışmış ifade ile insan hayatı üzerindeki denetim neredeyse mutlak hale gelmiş görünmektedir.

Ölümsüz Joe, köle haline getirdiği erkeklerden oluşturduğu militarist güçleri ile insan neslinin akıbetini belirlemeye başlamıştır. İnsanların Joe'nun varlığına gösterdiği biat, korku ve şiddetin yaşama egemen hale gelmesiyle sağlanır olmuştur. Lewis Dartnell, Uygarlığı Yeniden Nasıl Kurarız? kitabının "Toplumsal Sözleşmenin Yırtılıp Atılması" alt bölümünde, büyük bir kriz 
anında, "büyük bir afetten sonra (...) kalan kaynakların (yiyecek, yakıt vb.) kontrolünü ele geçirenler, yeni dünya düzeninde bir değer taşıyan her şeyi yöneteceklerdir" (Dartnell, 2016:32) diye yazdıktan sonra bu koşulların "yeni krallar"ın doğuşuna sebep olacağını iddia etmektedir. Mad Max: Fury Road filminde Ölümsüz Joe, demokratik toplumsallığın ortadan kalkışı sonrası her şeye egemen hale gelmiş olan yeni kralı sembolize etmektedir.

Uygarlık çökmüş, çok az bulunan suya ve petrole sahip olmak için şiddetli muharebeler başlamıştır. Tarım yapılacak verimli araziler neredeyse tamamen yok olmuş, çok sınırlı bir toprak parçasında tarımsal üretim yapılabilir hale gelmiştir. Tekno-endüstriyel uygarlık tamamen ortadan kalkmış, birkaç eski arabadan ve silah benzeri araçtan başka neredeyse hiçbir teknolojik ve teknik araç bulunamaz hale gelmiştir. İnsanlar susuzluğun ve kıtlığın sebep olduğu koşullarda sağlıktan yoksun bir biçimde yaşamlarını sürdürmektedir. İnsanların çoğunun susuzluktan derileri pörsümüş, dişleri dökülmüş, yara bere içinde ve hastalıklı bir halde varlıklarını devam ettirdikleri görülmektedir. İnsan ömrü uygarlık dönemine nazaran yarı yarıya azalmıştır. Bu koşullar altında yaşam, can havliyle ölümden kaçma ve ayakta kalma biçimini almıştır. İnsanlık idesi yerle bir olmuş, insan denilen varlığın vahşileştiği, yaşamın sürekli tehditler altında olduğu tekinsiz zamanlar başlamıştır. Ayakta kalan her canlının yaşamını anlatan düşünce filmin başında şöyle ifadelendirilir: "Benim dünyam ateş ve kandan oluşuyor!". Yaşama içgüdüsüne indirgenmiş hayat koşullarında, her canlı yaşamını idame ettirebilmek için elinden gelen tüm çabası ile ayakta kalmaya çalışmaktadır. İnsanı insan yapan hukuksal anlayışın ortadan kalktığı bu distopik evrende, insan aklının ürünü olan tüm değerler anlamını yitirmiş görünmektedir. İnsanın insan olma serüveninde antropolojik bir işlev taşıyan hukuk kavrayışı olmaksızın, artık insandan söz etmek imkânsız hale gelmiştir. İnsanlar arası ilişkileri düzenleyen hukuksal bakış açısı olmadığında, insan diğer bir insan için tüm anlamını kaybetmektedir. İnsanın akla sahip bir özne olduğu düşüncesinin asıl olarak hukuk tarihinin bir ürünü olduğunu yazan Alain Supiot, Homo Juridicus Hukukun Antropolojik İşlevi Üzerine Bir Deneme adlı eserinde, "hukuki açıdan insanı akla sahip ve vazgeçilmez ve kutsal hakları olan bir özne olarak kabul ederiz" (Supiot, 2014:36) diye yazmaktadır. Mad Max: Fury Road filminin oluşturduğu evren, insanların akla sahip hukuki özneler olduğu düşüncesinin ortadan kalktığ1 ilişkileri anlatmaktadır. Supiot'in, "insanın evrensel, soyut, özgür doğmuş ve akla sahip ve diğer insanlarla eşit oluşuna ilişkin Batılı insan anlayışımızın oluşması için Roma hukukundan modern hak bildirgelerine kadar uzan bir tarihsel yol gerekmiştir" (Supoit, 2014:37) diyerek söz ettiği hukuksal anlayış, tarihsel yol, Mad Max: Fury Road filminde anlamını tamamen yitirmiş görünmektedir.

Nükleer savaş sonrası uygarlık çökmüş, petrol savaşlarının ardından su savaşları başlamış, insanlık vahşileşmiş, yaşama terör egemen hale gelmiş, herkes kendi çıkarının peşinden koştuğundan ortak mutluluk yok olmuş, herkesin herkesle savaşı başlamıştır. Mad Max: Fury Road filminin girişinde aktarılan bu kısa öykü, post-apokaliptik zamanlarda geçen ana öykünün girizgahı biçiminde sunulmuştur. Bu giriş öyküsü ile insanların etik değerler üzerine inşa ettiği kültürel ilişkiler ve sosyal organizasyonların bir anda yerle bir olması olgusunu analiz etmek önemli görünmektedir. Mad Max: Fury Road filmi, insanlığın binlerce yılda oluşturduğu değerlerin aniden yerle bir olmasını anlatan bir eserdir. İlk Devletlerin Derin Tarihi-Tahıla Karşı adlı kitapta James C. Scott, “dünyanın önemli bir bölümünde devlet, güçlü olduğunda dahi gelip geçici bir kurum olmuştur" (Scott, 2019:29) diye yazmaktadır. İnsanların yaşamlarının değişik formları bulunmaktadır. Kalabalık insan topluluklarından uzakta bir 
yaşam biçimini sürdürebilmek de bu formlardan biridir. Ancak insanların büyük bir kısmı için günümüzde hala en önemli yaşamsal form, bir toplumsallık etrafında oluşturulmuş olanıdır. Spinoza, ortak yasalar olmaksızın ortak mutluluğun inşa edilemeyeceğini vurgulamıştır. İnsanların ortak yaşamını düzenleyen sosyal bir organizasyon aracı olarak devlet, Scott'un ifadesiyle her zaman gelip geçici olduğundan, insanlar arası ilişkileri düzenleyen etik değerlerin varlığı ve kalıcılığı her şeyden daha önemli hale gelmektedir. Mad Max: Fury Road filmini felsefi açıdan yorumladığımızda, insanlar arası ilişkinin ortak değerlerinin sarsılması durumunda, insanlar, bir tiranın baskı ve şiddetle kuracağı egemenliğe tabi olacakları günlere adım atacaklardır. Mad Max: Fury Road filmi vasıtasıyla, insanlığın ortak değerlerinin önemini tartışabilmek mümkündür. İnsanlığın ortak değerleri olmaksızın toplumsal ilişkileri düzenleyebilmek mümkün değildir. Scott'ın kitabındaki, “devletin, öz imgesine ve standart tarihsel anlatıların çoğunda sahip olduğu merkezi konuma rağmen, ilk kez sahneye çıkmasının ardından geçen binlerce yıl boyunca, insanlığın büyük bölümünün yaşantısında bir sabit değil bir değişken (ve hayli istikrarsız bir değişken) olduğunu unutmamak gerekir"( Scott, 2019:29) ifadesi, insanlığın geleceğini planlarken bu istikrarsızlıkları göz önünde bulundurması gerektiğini de vurgulamaktadır. Mad Max: Fury Road filmi, insanlığın hayatının kırılgan sosyal araçlarının geleceğine dair düşünmeye olanak sağlamaktadır. İnsanlığın hayatındaki kırılgan araçların varlığı, daha az kırılgan ortak insani etik değerlerin varlığının önemini ortaya çıkarmaktadır. Mad Max: Fury Road filmi, insanlığın tabiat durumuna dair yarattı̆̆ sinematografik imgeler yoluyla, etik değerler olmaksızın insanlığı nasıl bir geleceğin beklediğini bize anlatıyor görünmektedir.

Filmin açılış sahnesinde, ambulans ve itfaiye sirenlerinin eşliğinde, felaket haberlerine ait tonlama ile konuşan gazeteci, insanlığın yıkım çağının şahitlerinden biri olarak konuşur. Filmin ana kahramanlarından olan Max (Tom Hardy), filmin girişinde, her bir insanın deliliğinin diğerine üstün geldiği, ortak insani değerlerin yok olduğu bu çağda, adil bir gaye aradığı ifade eden içsesi ile, çölümsü araziye tepeden bakan bir yükseklikte yalnız kovboy imgesinin farklı bir versiyonu ile karşımıza çıkar. Herkesin, nereden geleceği belirsiz ölümcül tehditler karşısında, kaçmak durumunda olduğu bir uygarlıkta, Max de kaçmaktadır. Eski bir polis olan Max'in, sevdiklerini korumakta başarısız olduğunu ve bu kötü anılarının gündelik yaşamını karabasana dönüştürdüğünü film boyunca tekrar tekrar zihninde beliren kız çocuğu imgesiyle anlarız. Max'in kaçtığı, Ölümsüz Joe'nun Savaş Çocukları adlı askerlerinin kovaladığı bu sahneyle, film boyunca sürecek olan koşuşturmacaya dahil oluruz. Ölüm tehdidinin her yanı sardığı yaşamsal ilişkilerde, insanlar yaşamlarını sürdürebilmek için hep kaçmaktadırlar. Rousseau, tabiat durumunda insanların ayakta kalabilmek için kaçmak durumunda olduklarını, insanın kaçarken ilk öğrendiği şeyin, ölümün dehşeti olduğunu belirtir. Rousseau, İnsanlar Arasındaki Eşitsizliği Kaynağı adlı eserindeki söz konusu düşüncesini şöyle açıklamaktadır: “Ölümü, ölümün dehşetini bilmek insanın hayvanlık durumundan uzaklaşırken edindiği ilk kazançlardan biridir" (Rousseau, 2016:105). Rousseau'nun bu ifadesi, insanın, hayvandan insana geçiş yaparken, hayvani döneme ait baskın ölüm korkusundan uzaklaşmasıyla insan olmaya yaklaştığını vurgulamaktadır. Ölüm korkusunun sürekliliği, hayvani yaşamın egemenliğini göstermektedir. İnsanlar insanca bir yaşama geçiş yapmaya, ölüm korkusunun yarattığı tinsel huzursuzlukla baş etmenin mümkün olmaması sebebiyle, can güvenliğinin hukuksal garanti altına alındığı toplumsal sözleşmelerle ulaşmıştır. Toplum halinde yaşamak, hayvani yaşama ait korkuların üstesinden gelebilmek için, daha üstün bir 
yaşantıya ulaşabilmek için keşfedilmiştir. Rousseau, toplum kavramının doğada halihazırda bulunmadığını, aksine tabiat durumundan çıkış arayan insanların sözleşmesiyle oluştuğunu yazmaktadır. Bu düşüncesini Toplum Sözleşmesi adlı kitabında şöyle açıklar: "Toplum düzeni bütün öbür hakların temeli olan kutsal bir haktır: Bununla birlikte, hiç de doğadan gelme değildir, sözleşmelere dayanmaktadır" (Rousseau, 2013:4). Mad Max: Fury Road filminde, toplum kavramindan söz edebilmek mümkün değildir. İnsanlar can güvenliğinin olmadığ koşullarda, en temel insani ihtiyaçlardan dahi yoksun bir biçimde, kölelikten daha aşağ seviyelerde yaşamlarını sürdürmektedirler. Herkesin varlığına ve yokluğuna karar verebilecek kadar mutlak bir hakimiyet kurmuş olan Joe, Aristoteles' in özel alanın efendisini betimlerken kullandığı bir biçimde, tek bir yaprağın bile izinsiz kıpırdayamadığı bir evrenin efendisi konumundadır. Kamusal alan kavramının ortadan kalktığı, özel alana ait efendilik ilişkilerinin hayata yayıldığı bir dönem başlamıştır. Filmde, Furiosa'nın (Charlize Theron) Joe'nun egemenliğinden kurtardığı kadınların kendi aralarında konuşurken vurguladığı, "hiçbirimiz Joe' nun eşyası değiliz!" ifadesi, Joe'nun egemenliğini betimlemeye yardımcı olmaktadır.

Filmin ana kahramanları Max'in, Joe'nun Savaş Çocuklarından kaçtığı sahne, filmin üzerine inşa edildiği savaş sahnelerinin ilkidir. Max'in esir düşmesiyle sonuçlanan bu sahnede, Max, yaşamı idare eden ve yaşama egemen hale gelen duygunun ayakta kalma içgüdüsü olduğunu vurgular. Max, film boyunca çok az konuşmasına rağmen, birkaç sahnede Nietzsche'nin aforizmalarının yüzeysel yorumlarını anımsatan sözler sarf eder. İlk sarf ettiği söz, yaşama içgüdüsü ile ilgili olandır. Filmin sonuna doğru ise; umut etmenin anlamsız olduğunu vurgular. İnsani değerlerin değerinin değerlendirilmesinin sonucunda bu değerlerin değersiz olduğunu söyleyen nihilist bakış açısı, uygarlığın çöküşüne katkıda bulunmuş ve filmde anlatılan post-apokaliptik çağa böylece varılmıştır. Bu nihilist bakış açısı, Nietzsche'nin düşüncelerinin yüzeysel bir yorumundan kaynaklanmaktadır. Nietzsche, Ahlakın Soykütüğü kitabında, değerlerin değerlendirilmesinden, değerlerin yeniden tasnif edilmesinden söz etmektedir. Ancak değersiz addettiği değerlerin karşısında yeni değerler oluşturmak için bu değerlendirmeyi yaptığını da ayrıca belirtmiştir. Nietzsche, bu düşüncesini şöyle açıklar: "Ahlaksal değerlerin bir eleştirisine ihtiyacımız var, bu değerlerin değeri sorgulanmalı her şeyden önce -ve bunu yapmak için de bu değerlerin oluştuğu, geliştiği ve anlam kaymalarına uğradığı durum ve koşullar hakkında bir bilgi, (...), şimdiye dek var olmamış, hatta arzulanmamış türden bir bilgi gerekli" (Nietzsche, 2011:13). Nietzsche'nin düşüncesine göre; değerlerin eleştirisi yapılmalı, değerlerin değeri sorgulanmalı ve bunu yaparken şimdiye dek var olmamış ve arzulanmamış bir bilgi ile bu gerçekleştirilmelidir. Nietzsche'nin düşüncelerinin derinine inilmediği takdirde, onun düşüncelerinin nihilist yorumlariyla yetinmek durumunda kalınmaktadır. Nietzsche'nin nihilist bir kavrayışın mimarı olduğu hakkındaki yüzeysel değerlendirme, Mad Max: Fury Road filmi gibi popüler kültürel eserler aracılığıyla yeniden üretilmektedir. Max karakterinin adil bir gayeden yoksun oluşu, içgüdüleriyle hareket edişi, gelecek umudunu anlamsız bulması, Max'i nihilizmin düşünce dünyasına yaklaştırmaktadır. Ancak filmin geneli göz önünde bulundurulunca, Max'in nihilist kavrayışa özgü kendinden vazgeçme dürtüsünü aşarak, Furiosa ile birlikte Hisar Dağı'nı ele geçirmek için gösterdiği çaba ile yeni değerlerin yeşereceği bir davranışa yöneldiğini de göstermiştir.

Max'in esir düştüğü sahnenin ardından, sinematografik anlatım, Joe'nun egemenliğinin ayrıntıları hakkında fikir edinmemize yaramaktadır. Yarı karanlık mağaralarda, Savaş 
Çocukları, esaret altındaki insanlara işkenceye varan uygulamalarda bulunmaktadır. Kısmen sağlıklı insanların kanlarını savaşçılara transfer ederek, savaşçıların bedensel takatinin artırılmaya çalışıldığını, doğurganlık sahibi kadınların sütlerinin depolandığını ve bu sütlerin sağlık kaynağı olarak ayrıcalıklı savaşçılara sunulduğunu görürüz. Joe'nun sembollerinin insanlara kızgın demirlerle işlendiği sahne, tiranik bir egemenliğin boyutlarını aktarmak açısından önemli sinematografik imgeler olarak yansıtılmıştır. Ölümsüz Joe'nun törensel konuşması öncesinde, üzerine giydiği kostüm, savaşçı toplumlara özgü sembollerin kullanımının, uygarlığın çöküşünden sonra da varlığını devam ettirdiğini gösteren imgelerden olmuştur. $\mathrm{Bu}$ göstergeler, tiranik bir egemenliğin mitler ve semboller olmaksızın kurulamayacağını da anlatmaktadır. Film boyunca, savaşçıların kullandıkları bayraklar, savaşın ritmine eşlik eden müzikler, savaş̧̧ıların ölümsüz olma isteklerini yansıtan ifadeler, post-apokaliptik bir evrenin işleyişinde, mitlerin ve sembollerin işlevini yansıtmaktadır. Ölümsüz Joe'nun savaşçılarına Valhalla adlı İskandinav mitolojisinde bulunan efsanelere dayanarak, ölümsüzlük bahşettiğini birçok sahnede görürüz. Savaşçlların korkusuzca ölüme doğru atılmalarının ardındaki motivasyon, söz konusu mitolojideki ölümsüzlükten pay alacaklarını düşünmeleridir. Ölümsüz Joe'nun, savaşçılarının zihni üzerindeki egemenliği, film boyunca hissedilir. Ölümsüz Joe'nun gözlerinin içine baktığını söyleyerek, heyecandan çılgına dönen savaşçının olduğu sahne, Joe'nun egemenliğinin sembolik yanını göstermesi açısından ayrıca önemli bir sinematografik imge olmuştur.

Ölümsüz Joe, Hisar Dağı'ndan Gaz Şehri'ne gitmek için, Furiosa'nın başında olduğu bir konvoyu görevlendirir. Konvoyun yola çıkmasından önce yapılan törensel etkinlik, görevin, metafizik çağrışımlarla yüklenmiş ulvi bir görev olduğu hissini pekiştirir. Joe'nun "ben sizin kurtarıcınızım!" diyerek seslendiği bu konuşma esnasında, insanların çaresizlik ve korku içerisinde itaatkâr bir biçimde tezahürat ettikleri görünür. Hisar Dağı'nın tepesindeki vanaların açılmasıyla, susuzluk içerisindeki insanlara sınırlı miktarda su verilir. En temel gereksinimlerini doyurabilmek arzusunda olan insanların, çaresizlik içinde birbirlerini ezercesine rekabet ettiklerini izleriz. Bu çaresiz ve bedbaht hal içerisindeki insanlara, Joe' nun öğüdü, bir tiranın kibrini açıkça belli etmektedir. Joe, "suya bağımlı olmayın, yokluğunda kırılgan olursunuz!" diyerek seslenir. Antik Dünyada Su ve İktidar adlı kitabında Steven Mithen, "su ve iktidar arasında karmaşık bir ilişki olduğunu" yazmaktadır ve ayrıca "iktidara sahip olmanın yolu, suya erişimi kontrol altına almaktan geçer" (Mithen, 2017:304) tespitinde bulunur. Farklı uygarlıklarda suyun denetiminin iktidar ile ilişkisini incelediği söz konusu kitabında, "su tarih boyunca savaşlarda kullanılan bir silah olmuştu, bu durum günümüzde de devam etmektedir" (Mithen, 2017:305) diye belirtir. Joe'nun egemenliğinin en önemli dayanaklarından biri de su kaynakları üzerindeki denetimi ile ilişkilidir. Furiosa'nın film boyunca ulaşmaya çabaladığı Yeşil Vadi, insani yaşama elverişli bir ortam sunan su kaynaklarının bulunduğu arazidir. Ancak Furiosa, uzun ve tehlikeli bir yolculuktan sonra, bu vadinin kargalarla kaplı bir bataklığa dönüştüğünü öğrenir. Furiosa'nın derin bir üzüntüye kapıldığı bu sahne, suyun insanlığın her döneminde yaşamın temel dayanağı olduğunu ayrıca vurgulamaktadır.

Hareketli kamera kullanımının yaygın olduğu filmde, kamera, esaret altındaki insanların yüzlerine duygulanım imgeleri yansıtmak açısından yaklaşmış, bu sahnelerde, egemen olan ile egemenliğe tabi olanların tinsel varoluşlarını insanların yüz ifadelerinden okuyabilmek mümkün olabilmiştir. Furiosa'nın öncülüğünde Gaz Şehri'ne doğru yola 
çıkıldığında, kamera hareketlerinin yardımıyla, konvoyun bir parçası olan tüm savaşçıların davranışlarına odaklanabilmek imkânına ulaşılmıştır. Furiosa'nın duygulanımlarını, Savaş Çocuklarının paniğini yansıtmak maksadıyla, kameranın hareketleri, devinim halindeki sahnenin farklı açılarını sunabilmiştir. Konvoydaki savaş araçlarının üzerinden yapılan çoklu kamera çekimleriyle, oluşan panik duygusunun seyirciye aktarılması sağlanmıştır.

Filmin ana öyküsünün üzerine inşa edildiği üç önemli savaş sekansı bulunmaktadır. İlki, Furiosa' nın güzergah dışına çıkmasıyla, Joe'nun kendisine ihanet edildiğini fark etmesiyle gelişen takip sekansıdır. Bu sekansta, Furiosa'nın, Joe'nun neslinin devamı için ihtimamla yetiştirdiği, sakladığı, gözettiği kadınlar ile birlikte Yeşil Vadi'ye doğru yeni bir yaşam oluşturma fikriyle hareket etmesi etrafında gelişen olaylar aktarılır. Furiosa'nın kendisini takip eden savaşçılardan kısa bir zaman için de olsa uzaklaşmasıyla bu sekans tamamlanır. Max'in savaş çocuklarının elinden kurtulmasını başardığı bu sekansta, Max ile Furiosa, ister istemez ortak hareket etmek durumunda kalırlar. Furiosa'nın hayaline giden yol ile kendi yoluna gitmeyi arzuladığını söyleyen Max'in yolu böylece birleşir.

Max ile Furiosa'nın ortaklaşarak Yeşil Vadi istikametine yönelmeleriyle, ikinci önemli savaş sekansı gelişir. Savaş Çocuklarının yeteneklerini göstermek için birbirleriyle yarıştıkları, Joe'nun gözüne girmek için fırsat aradıkları bu sekansta, filmin ses, müzik, kamera hareketleri, renk açısından en etkili olduğu sahneler oluşturulur. Savaşa ait atmosferin farklı veçhelerinin oluştuğu bu sekansta, ateşli silahları, savaş tekniğine dahil olmuş akrobatik hareketleri, savaşın ritmini körükleyen müzik aletlerini, çölün toza, dumana karışmasını, gökyüzünün renginin değişmesini gelişmiş kısa çekimlerin sağladığı hızlı kurguyla izleriz. Savaşın dehşetinin ayrıntılı bir biçimde imajlara aktarıldığı bu sahne, yeryüzündeki insani yaşama koşullarının olanaksızlığının da hissedilmesine yardımcı olur. Savaşın hengamesinin yaşandığı bu anlarda, izleyici iklimsel olarak ani değişimlere tanık olur. Havanın aniden karardığı, gökyüzünün renginin değiştiği, ani fırtınanın geliştiği bu sahneler, nükleer felaket sonrası iklimin dengesinin artık iyiden iyiye bozulduğunu işaret etmektedir. Çorak yeryüzü, tozlarla kaplı gökyüzü ve yaşama egemen hale gelmiş savaşın birlikte sunulduğu bu imajlar, insanın geleceğe dair umudunun tükenmeye yüz tuttuğunu da vurgulamaktadır.

Furiosa ve Max, ikinci savaş sekansının sonunda, Furiosa'nın çocukluğunun birlikte geçtiği insanların yanına varmayı becerirler. Meşakkatli bir serüvenin sonunda, varılan bu yer, yeni yaşamın filizleneceği bir yer olma umudu taşımaktadır. Ancak, umutlar bir anda yerini derin umutsuzluğa bırakır. Çünkü; Yeşil Vadi günleri geride kalmış, iklimsel değişimler orayı da etkilemiş ve yeryüzünün son cennet köşelerinden olan bu yer artık bataklığa dönüşmüştür. Furiosa, son bir umutla, uzaklarda başka bir vadiye doğru yola çıkmayı önerir. Bu düşüncenin tartışıldığı esnada, Max, eldeki kısıtlı imkânları da gözeterek, Hisar Dağını ele geçirmeyi teklif eder. Filmin son savaş sekansı, bu noktadan sonra gelişir. Umutsuzluğun, güvensizliğin, rekabetin, özel çıkarların yaşama egemen olduğu bir çağda, Max ve Furiosa'nın birlikte harekete geçmesiyle, insanlığın umudu yeniden belirir. Yeni bir yaşamın oluşabilmesi için atılmış bu adım ile, Hisar Dağı ele geçirilir. Yeni bir toplum için toplumsal sözleşmenin tasarlanabilmesi, bu aşamadan sonra gerçekleşme imkanı bulabilecektir. 


\section{Sonuç}

Mad Max: Fury Road filmi, post-apokaliptik bir distopya örneği olarak, yaklaşan gelecek hakkında insanlığı düşünmeye sevk eden sinematik imgeler barındırmaktadır. İnsanlığın tabiat halinden çıkarak demokratik toplumsallıklara ulaştığı uzun yıllara dayanan düşünsel gelişmeler, insanlığın tüm değerlerinin ortadan kalkacağı distopik gelecek tahayyülü karşısında yeni bir okumaya tabi tutulabilir. Siyasal kuramların tabiat hali hakkındaki tasvirleri ile distopik eserlerin tabiat hali tasvirleri, tabiat halinin anlamına dair düşünmeye imkân vermektedir. İnsanlık, tabiat haline üstün bir yaşantıyı oluşturabilmek için önemli merhaleler kat etmiştir. Tabiat halinin felsefi anlamı üzerine düşünmek, tabiat haline üstün bir yaşantı olarak demokratik toplumsallıkların anlamını ortaya çıkarmaktadır. İnsanlığın, distopyalar çağının girişinde, yaklaşan tabiat haline karşı zihni farkındalık kazanması, distopyaların yarının gerçeği olması ihtimalini kısmi anlamda azaltabilir. Mad Max: Fury Road filmi, tabiat haline dair sinematik imgeleri ile felsefi anlamda bir tartışmanın zemini için faydalı bir eserdir.

\section{Kaynakça}

Cioran, E. M. (1999). Tarih ve Ütopya. (B. Haldun , Çev.) İstanbul: Metis.

Claeys, G.(2011). Distopyanın Kökenleri: Wells, Huxley ve Orwell. Gregory Claeys içinde, Ütopya Edebiyatı. (Z. Demirsü, Çev.)(s. 155-190). İstanbul : İş Bankası Yay.

Clastres, P.(2017). Şiddetin Arkeolojisi İlkel Toplumlarda Savaş. (S. Tuna, Çev.) İstanbul: Nora Kitap

Dartnell, L. (2016). Uygarlı̆̆ı Yeniden Nasıl Kurarız. (Ö. Bircan, Çev.) İstanbul: Koç Üniversitesi Yayınları.

Gordin, M., Tilley, H., \& Prakash, G. (2018). Ütopya-Distopya Tarihsel Olasıllğıı Koşulları. (A. Turan, E. Kartal, \& C. Kayalıgil, Çev.) İstanbul: Koç Üniversitesi Yay.

Hobbes , T. (2013). Leviathan. (S. Lim, Çev.) İstanbul: Yapı Kredi Yay.

Mithen, S. (2017). Susuzluk Antik Dünyada Su ve İktidar. (E.Kılıç, Çev.) İstanbul: Koç Üniversitesi Yay.

Nietzsche, F. (2003). İnsanca Pek İnsanca 1. (M. Tüzel, Çev.) İstanbul: İthaki Yay.

Nietzsche, F. ( 2005). Yazılmamış Beş Kitap İçin Beş Önsöz. (G. Aytaç, Çev.) İstanbul: Say Yay.

Nietzsche, F.(2011). Ahlakın Soykütüğü Bir Polemik. (Z. Alangoya, Çev.) İstanbul: Kabalc1 Yay.

Platon. (2003). Devlet. (S. Eyüboğlu , Çev.) İstanbul: İş Bankası Yay.

Rousseau, J. ( 2013). Toplum Sözleşmesi. (V. Günyol, Çev.) İstanbul: Rousseau,J.J., Toplum Sözleşmesi, Çev.: Vedat Günyol, İş Bankası Yay., 2013, İst., syf:4.

Rousseau, J. (1995). İnsanlar Arasındaki Eşitsizliğin Kaynağı. (R. İleri, Çev.) İstanbul: Say Yay.

Rousseau, J. (2015). Emile. (Y. Avunç, Çev.) İstanbul: İş Bankası Yay. 
Scott, J.C. (2019). Tahıla Karşı İlk Devletlerin Derin Tarihi. (A.E. Pilgir, Çev.) İstanbul: Koç Üniversitesi Yay.

Supiot, A. (2014). Homo Juridicus Hukukun Antropolojik İşlevi Üzerine Bir Deneme. (B. Açımuz, Çev.) Ankara: Dost Kitabevi Yay.

Spinoza, B. B. (2007). Tractatus Politicus. (M. Erşen, Çev.) Ankara: Dost Kitabevi.

Warner Bros., Village Roadshow Pictures, Kennedy Miller Productions ve diğerleri (Yapımcı), \& George Miller (Yönetmen). Gösterim Yılı (2015). Mad Max Fury Road.[Sinema Filmi]. A.B.D 